\title{
ENGLISH LANGUAGE TEACHING METHODOLOGY IN A CALL CLASSROOM:TESTING AND EVALUATING TRADITIONAL GRAMMAR INSTRUCTION
}

\begin{abstract}
Pursuant to the revised Research Policy issued by the Executive Committee of the European Association for Computer Assisted Language Learning, research in the area of ComputerAssisted Language Learning (CALL), should guide language pedagogies rather than the availability of new technologies and functionalities. Accordingly, the aim of this research was to test a combination of methods and techniques rooted in traditional grammar instruction by alternating them in a conventional classroom setting (based on paper and a whiteboard) and an experimental CALL setting. The hypothesis was that if the classroom activities were anchored in traditional grammar teaching methodology, the CALL environment would prove as comprehensive as the conventional classroom, thus stimulating and yielding positive results. By means of grammar-based teaching and communicative learning the grammar item "meaning of modal verbs" was taught. Based on a quasi-experiment and the principles of a repeated measures research design, the performance of 50 students at two English language departments was alternatively measured in both the conventional and the experimental classroom settings in several subsequent instances. The analysis of the data resulted in the conclusion that the overall performance of the participants in the experimental setting exceeded the performance in the conventional setting.
\end{abstract}

Keywords: Computer-Assisted Language Learning, English language teaching, teaching methodology, traditional grammar instruction.

\section{Introduction}

The term Computer Assisted Language Learning (CALL) came into use in the early 1980s and the leading professional associations (EUROCALL, CALICO and IALLT) define CALL as use of computers in foreign language learning and teaching in its broadest sense (word-processors, Internet, etc.), but not the use of specific items of modern technology (mobile phones, tablets and pads). A widely accepted definition is that CALL means "the search for and study of applications of the computer in language teaching and learning" (Levy, 1997:1), or "any process in which a learner uses a computer and, as a result, improves his or her language" (Beatty, 2010:7).

1 E-mail: jasmina.djordjevic@filfak.ni.ac.rs 
A detailed review of the possibilities of digital technology and CALL in the language classroom would exceed the scope of this research. Yet, the benefits of technology could be summarised as follows:

1. Implementation of an unlimited choice of multimedia resources, applications and authentic material which can be adapted to fit both curriculum requirements and student needs (Cennamo, 1993; Vanderplank, 2010).

2. More individuality and autonomy are provided to the students as they can contribute ideas and material while being in charge of their own study and research time. (Murphy, 2008);

3. Faster feedback and direct communication with the students further self-correction and error management skills, thus contributing to a rise in self-confidence (Hyland, 2000; Skehan, 2003).

4. Motivation is furthered both among students and teachers. Interesting and challenging content helps students focus, thus motivating them to work harder (Cheng \& Dörnyei, 2007; Noels, 2001) whereas teachers are challenged to experiment and research, thereby developing their personal skills and interests (Beatty, 2010).

Regardless of its many investigated and proven benefits and advantages, CALL is a rather young branch of applied linguistics and it is still establishing its directions (Beatty, 2010). Theoretical explorations within this discipline are facing the same problems as any other newly-established discipline within linguistics up to now - there is either too much or too little research (Hall, 2011). Although different perspectives and frameworks have been suggested by various authors, ranging from general Second Language Acquisition theories (Chapelle, 1997) to sociocultural, systemic-functional linguistics, anthropology, ethnography and semiotic theories (Kern, 2006), a common consensus regarding the theoretical grounding of the CALL field seems to be missing (Kern, 2006).

More research should be directed at exploring and mapping out this area from a theoretical point of view (Cameron, 2001; Levy \& Stockwell, 2013). Such research would not only enable the acceptance of CALL as a valid discipline (Beatty, 2010) but also contribute to clarifying questions regarding how online and offline tools can be utilised for the purpose of achieving learning objectives (Stockwell, 2007). In support of the idea that more research should be directed at the theoretical aspects of CALL, the Executive Committee of the European Association for Computer Assisted Language Learning (EUROCALL) decided in 2010 that the research policy statement formulated in 1999 should be revised as many changes had happened and they should be accounted for, especially in the domain of pedagogy. The policy now focuses on the idea that CALL research should guide language pedagogies and not the availability of new technologies and functionalities.

A large pool of research has been directed at justifying the pedagogical implications of CALL. Chapelle (1997) suggested that the main research focus in the next decade should be on methods that complement the understanding of the language experience learners have in a CALL setting. A decade later Colpaert (2006) stated that an approach based on technology needs a pedagogy based on the advantages and the innovative features of a new medium. Ellis and Bogard (2007) suggested that CALL opens new opportunities to 
apply what we already know about SLA to second language instruction, whereas Koehler and Mishra (2008) insist that CALL, just as any other teaching approach, must rely on three components: content, pedagogy and technology. In brief, more empirical research should be shifted from the tendency of exploring the possibilities provided by available tools, programs and various gadgets in a CALL environment to the techniques and procedures of teaching with them (Thompson \& Mishra, 2008).

Following the outlined recommendations, this article seeks to investigate whether the CALL environment will prove as comprehensive as the conventional classroom, thus stimulating and yielding positive results if the classroom activities are anchored in traditional grammar teaching methodology. For that purpose, 50 students at two English language departments participated in a quasi-experimental research study which was based on a repeated measures design. During three 90-minute sessions, the students were exposed to a combination of methods and techniques based on traditional grammar instruction alternatively conducted and tested in a conventional classroom setting (based on paper and a whiteboard) and an experimental CALL setting.

\section{Grammar instruction in ELT and CALL}

During the last fifteen years, attitudes regarding the importance of teaching grammar have shifted significantly indicating the necessity of re-introducing grammar instruction in language teaching (Azar, 2007; Ellis, 2002; 2006; Mulroy, 2003; Nassaji \& Fotos, 2004; Pennington, 2002; Teruya 2009; Thornbury, 2002). Nassaji \& Fotos (2004) stated that grammar is necessary for language learners to attain high levels of proficiency in the language they study. Thornbury (2002) pointed out that grammar is a tool for making meaning, enabling speakers to express themselves fully, and Teruya (2009) identified grammar as a meaning-making resource. Ellis (2006) re-evaluated the effectiveness of grammar teaching and concluded that there is enough evidence to demonstrate that grammar teaching works. Mulroy (2003) discovered that native speaking secondary-school students in the USA seem to be unable to understand complex linguistic forms in their own language due to insufficient grammar instruction. Pennington (2002) stated that grammar represents the organising principles of a linguistic, i.e. communicational system, and Azar (2007) stressed the importance of the fundamental understanding of grammar concepts to effective language use. Yet, all these authors point out that students should not be instructed to learn grammatical rules, but rather taught how to understand and acquire the meanings conveyed by grammatical forms and how to use them in communication.

Several attempts at exploring grammar instruction within a CALL model can be found in the literature (Akakura, 2012; Al Jarf, 2004; Baturay et al., 2010; Coniam, 2006; Fernando, 2007; Jarvis \& Szymczyk, 2010; Vance 2012; Wold, 2011). For instance, Jarvis and Szymczyk (2010) discovered that students generally preferred working with paper-based materials although they were quite aware of the advantages of the use of computers in general. When investigating the difference between student performance in tests based on paper and in tests based on the computer, Coniam (2006) concluded that the performance with computer-based tests was generally better than with traditional paper-based 
tests. Fernando (2007) explored the theoretical support of teaching through podcasting based on existing language acquisition theories and Wold (2011) tried to provide a cohesive instructional model by means of a combination of e-learning and conventional learning. Vance (2012) discovered that students prefer to have both Web 2.0 and Web 1.0 elements incorporated in the courses they take. The difference between the two is crucial as Web 1.0 allows only the use of content while Web 2.0 allows altering and sharing of content. In other words, blogs, wikis, collaboratively designed documents and resources as well as various sharing platforms, now add a new component to the teaching process - that of students contributing content and ideas within an interactive and collaborative setting. However, research into the methodology of teaching grammar in a CALL setting in terms of an efficient and structured system of teaching seems scarce.

That is the reason why the quasi-experimental research conducted for the purpose of this article was aimed at exploring the extent to which traditional grammar instruction in a CALL environment may prove effective.

\section{Method}

\section{Design, sample, setting}

Although based on a thoroughly planned repeated measures design, the empirical research conducted for the purpose of this article may be considered only a quasi-experiment. The obvious limitations that have to be pointed out are that it was restricted in time, space and the number of participants, that it was related to one grammar learning objective and a single grammar item so that it can serve only as an illustration. In order to make sure that the quasi-experiment would yield valid data despite its limitations, it was conducted two times at two different English language departments, with 25 participants each time, all of them second-year students following a rather similar English language curriculum.

Prior to the research, the students were asked to complete an anonymous questionnaire asking about their age, gender and how frequently they used the computer for their studies (the proposed answers: never, frequently, every day). The subsequent analysis showed that the average age of the participants was 20 years suggesting no obvious discrepancy in experience. Pursuant to the common trend of more female than male students at language departments, more female students participated in the research, i.e. a total of 33 female students as opposed to 17 male students (17 female students in the first group and 16 in the second group, i.e. 8 male students in the first group and 9 in the second group). With respect to the participants' use of the computer, they all stated that they used the computer every day for their studies.

The research was conducted during the winter semester of the school year 20142015, i.e. in November 2014 with the first group at the Faculty of Law and Business Studies in Novi Sad and in December 2014 with the second group at the Faculty of Philosophy in 
Niš. Both times, three 90-minute sessions were conducted. The conventional and the experimental settings were alternated in each conducted session and the performance of the participants was alternatively measured in both the conventional and the experimental settings in several subsequent instances.

Prior to the research a detailed analysis of the syllabi at each language department was performed and both instructors conducting the practice classes focused on grammar at each of the departments were interviewed (lectures in grammar were provided by a professor in both cases). The instructors were asked to state the approach they applied when presenting and practising grammar items as well as the devices and the practice material they used. The syllabi proved to be similar while the interviews can be summarised as follows: both instructors applied traditional grammar instruction based on the three 'Ps' combined with a communicative approach (details will be supplied in the next section), they did not use any technology, they were both in favour of the board and chalk, they used their own material based on various grammar books (the favourite ones being Thomson \& Martinet, 1990 and Murphy, 1998) and they supplied hand-outs with language activities (fill-in-the-blanks, match, listening comprehension, reading comprehension, etc.). It could be concluded that the samples were rather similar in regard to background knowledge and prior learning experience so the basic requirements of controlled experiments in general, i.e. that of randomization and equalizing was met.

The preparatory steps for the experiment included a consent letter for all participants and the opening of 25 different email addresses on several different account providers (gmail, yahoo and msn). Each email address was connected to the PBworks workspace (PB) (available at http://modalverbsmeanings.pbworks.com/w/browse/\#view=ViewAllObjects) created for the purpose of the experiment (see Figure 1). To ensure the anonymity of the results, the participants were instructed to use their email accounts and PB access details as their identification in the Answer Sheets (AS) prepared for all the activities and tasks conducted in both the conventional and the experimental settings. The students were also instructed to enter all their answers into the ASs so that the sheets could later be coded, marked and used for the assessment of their performance.

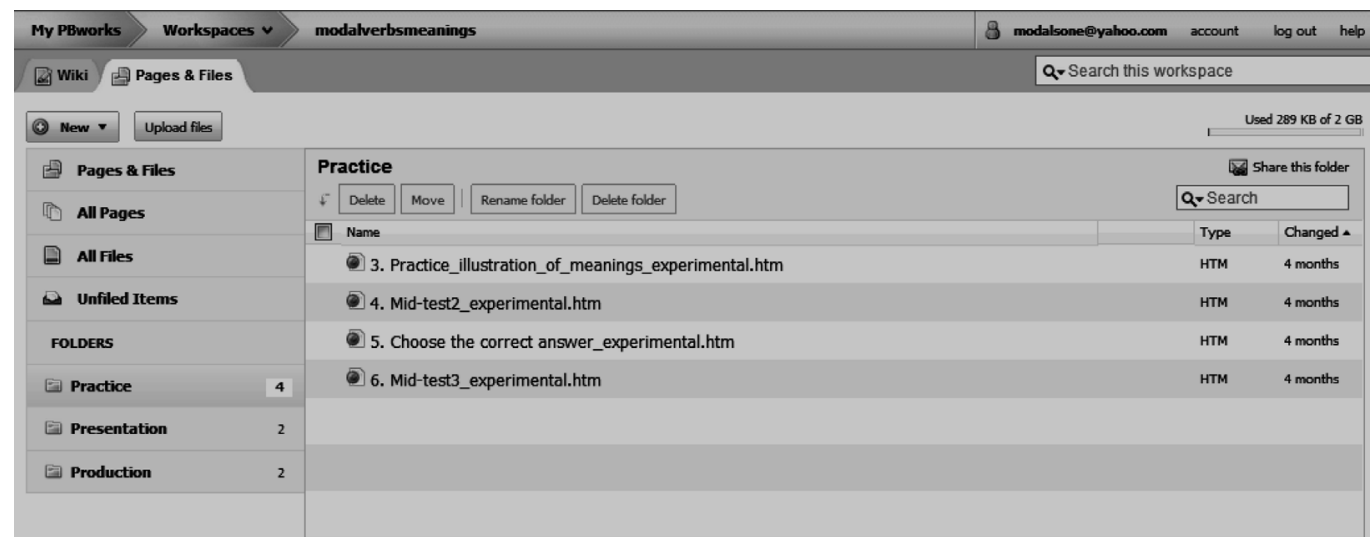

Figure 1. Illustration of the practice page on the workspace on PBworks. 


\section{Traditional grammar instruction implemented in the experiment and the procedure}

The choice of instruction model for the purpose of this research was based on two criteria: 1) it had to fit both types of settings in the experiment - the conventional classroom and the CALL environment and 2 ) it had to be anchored in a firmly grounded pedagogy. Therefore, the experiment was conducted based on the Presentation-PracticeProduction model or the 'three Ps', a traditional activity sequencing pattern suitable for various types of content and activities. Although one out of many available pedagogical techniques for the modern language classroom, Cook (2008) identified this pattern as the mainstream EFL teaching style and Sánchez (2001) referred to it as the school model. Despite criticism (Carter \& Nunan, 2001; Harmer, 1996; Lewis, 1996; Scrivener, 1994; Woodward, 1993), a rather firmly grounded pedagogical tradition and the experience of both learners and teachers do speak in favour of teaching and learning a foreign language in this way (Swan, 2005).

Following the three-Ps model, a particular grammatical item should be presented, described and explained, then practised within an adequate and illustrative communicative context and finally, tested to ensure proper production. Authors of language teaching methodology (Azar, 2007; Broughton et al., 1978; Harmer, 2001; Richards \& Renandya, 2002; Ur, 1991) suggest various techniques for the purpose of teaching grammar, such as problem-solving, explanations, time lines, drills, written practice, pair work, role plays, etc. The techniques applied in this research followed the three-Ps model:

(a) Presentation techniques: previewing, text study, problem-solving, isolation, modelling, explanations, writing on the board, drawing time lines.

(b) Practice techniques: drills, written practice, games, interaction activities.

(c) Production techniques: pair work, purposeful writing.

The grammar item presented, practised and produced in the experiment was the meaning of modal words. Again, a large pool of resources can be found in the literature on teaching modal verbs (Azar \& Matthies, 2003; Brown, 2000; Harmer, 2001; Lightbrown \& Spada, 2006; Nunan, 2005; Parrott, 2000; Richards \& Rodgers, 2014; Thornbury, 2002; Ur, 1991). For instance, Parrot (2000) explained that learners often consider modal verbs to be particularly problematic and that they sometimes find it confusing that one model verb may have several meanings or functions. Azar \& Matthies (2003) warned that the use of the wrong modal auxiliary can result in confusion and misunderstanding. The solution to the problem according to the above-mentioned authors is to relate the particular modal to the communicative context, which can best be achieved through a combination of grammar-based teaching and communicative learning, which is why these two approaches were applied in the experiment as well. Two main reasons may be listed to justify this decision: 1) these two approaches had been used by the teachers in both groups of participants and 2) grammar-based teaching relies on many different types of relevant theoretical presentation (Azar \& Matthies, 2003; Nunan, 2005; Parrot, 2000) whereas communicative learning focuses on the function of language providing plentiful exposure to language use (Brown, 2000; Harmer, 2001; Richards \& Rodgers, 2014). 
The mentioned authors agree that the most important modal aspect to recognize is what the speaker wants to communicate in a particular situation, i.e. that modal verbs are polysemic and that they have an epistemic function in a certain communicative context. Thus the preliminary research, as well as the pilot research conducted prior to the experiment, led to the conclusion that the choice of modal verbs and their meanings to be taught in the experiment should be based on the following criteria:

(a) they are used most frequently in speech,

(b) they fit the content the students had already covered in their regular lessons,

(c) they fit the polysemic approach and

(d) they can be presented, practised and produced in the exact same way with paper-based material and by means of tools available online.

The review of the available literature mentioned here led to the conclusion that the separate meanings of modal verbs as well as types of modals, semi-modals and modal idioms may be divided in eight groups of meanings: possibility/ probability (can, could, may, might, can't, must), ability (can, could, be able to), permission (can, could, may, might, be allowed to), prohibition (must not, be not allowed to), advice/ recommendation/ expectation (should, ought to), obligation (must, have to), necessity (need, have to) and absence of obligation or necessity (don't have to, need not, needn't have). These meanings were then alternatively presented, practised and produced within the experimental and the conventional settings by means of a total of 135 sentences, each designed to focus on one single meaning while following the same patterns and model in both settings. After each completed activity, the students' performance was measured in the form of short tests, again prepared either in the form of a web-based tool or a paper-based hand-out, depending on the way the activity had been conducted. In both settings, the teacher constantly communicated with the students whereby interaction and collaboration among the students was being encouraged in all the separate steps, except in the case of the examples used in the measuring tests as they had to be done individually.

The material in the teaching process in the experimental setting was accessed through the workspace PBworks that had been created for that purpose (see Figure 1). All activities prepared for both the experimental and the conventional setting were based on the same type of tasks with the only difference that for the experimental setting they were web-based (created in Hot Potatoes and Dvolver and accessed through PBworks) and for the conventional setting, they were paper-based (distributed as hand-outs). For instance, in the case of the dialogues used for the presentation session (see Figure 2), the meanings were presented in the form of short cartoons that could be accessed through the PBworks space in the web-based presentation, whereas in the paper-based presentation, the dialogues were typed out and for each meaning two students were asked to read out the dialogues. The following section will provide more details regarding the performance of the participants. 

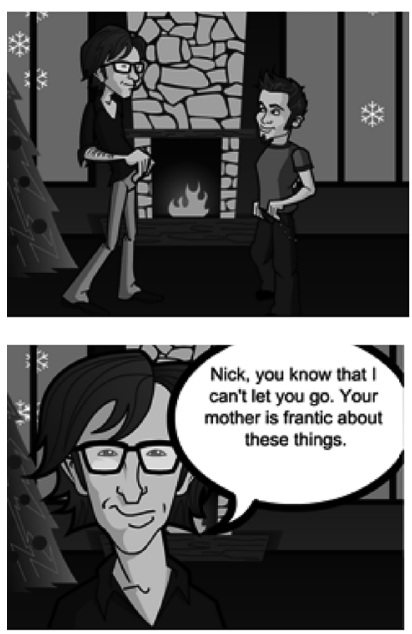
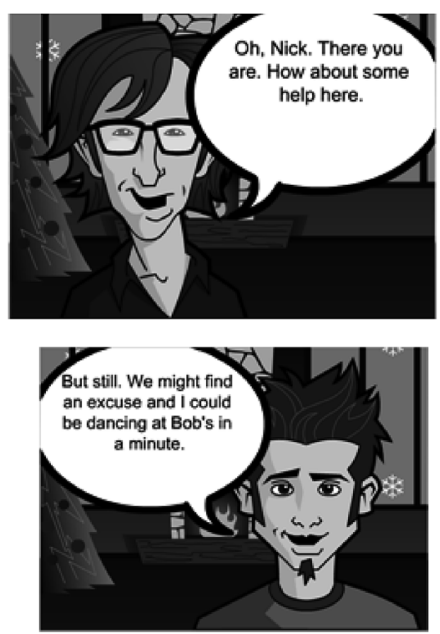
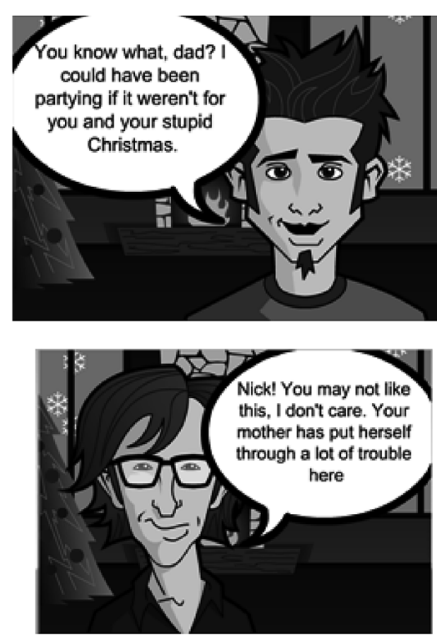

MEANING

A: I am having some problems with my car these days. I can't start it in the morning.

B: Why don't you have a mechanic take a look at it? They are able to detect such pro-

ability blems, aren't they?

A: Well, yes. But the last one I went to could not do a thing because he didn't have the right tools.

prohibition A: You mustn't walk on the grass. They'll fine you if they see you!

B: I don't care. Nobody can tell me what I am or am not allowed to do.

obligation A: Oh, God. I really have to go. My mother is expecting me for lunch.

B: Ok. I'll be leaving, too. I must go to the library because I need some information about the Civil War.

A: I have to buy a new sweater for the party tonight. Mary wants us to wear the same colours.

B: To be honest, I would waste money on a new sweater only if I needed to replace some really old one.

Figure 2. Comparison of several scenes created in Dvolver presenting the meaning of probability/possibility (above) and conventional dialogues presenting the meanings of ability, prohibition, obligation and necessity prepared as a hand-out (below). 
The fill-in the blanks activity looked quite the same (see Figure 3). In the web-based tool they could ask for help by clicking on the help button, which would provide the first letter and it provided immediate feedback in the tool itself by marking the answer as correct or incorrect. In the paper-based activity, both help and feedback had to be requested from the teacher.

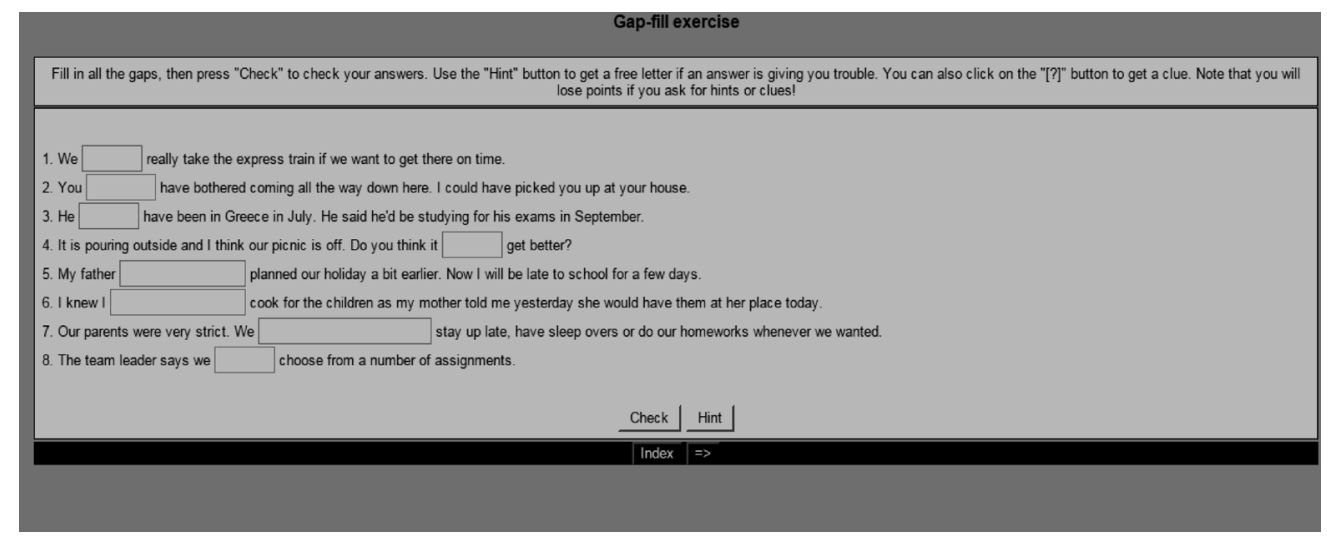

1. Listen, you freak! You smoke in here. It's a hospital for crying out loud.

2. My father walk for three months after the accident. It was a really difficult time for him.

3. I really. practise a bit more if I want to make this term.

4. Kids, the sign says you touch the dolls! They are part of the exhibition.

5. When we got to the top of the hill, we see the entire city.

6. A passport be obtained on time!

7. She really get her life back on track if she wants succeed in at least something.

8. Visitors put on protective gloves as soon as they enter this floor.

Figure 3. Comparison of a fill-in-the-gap exercise accessed through the workspace on PBworks created in Hot Potatoes (above) and prepared as a hand-out (below).

In the activity based on a crossword puzzle (see Figure 4), the clues in the web-based version were integrated in the tool and the students had to click on them to see them, whereas in the paper-based activity the clues were given below the crossword puzzle. Again, the web-based activity provided the option for help and feedback whereas for the paper-based activity, the students could ask the teacher for assistance. 

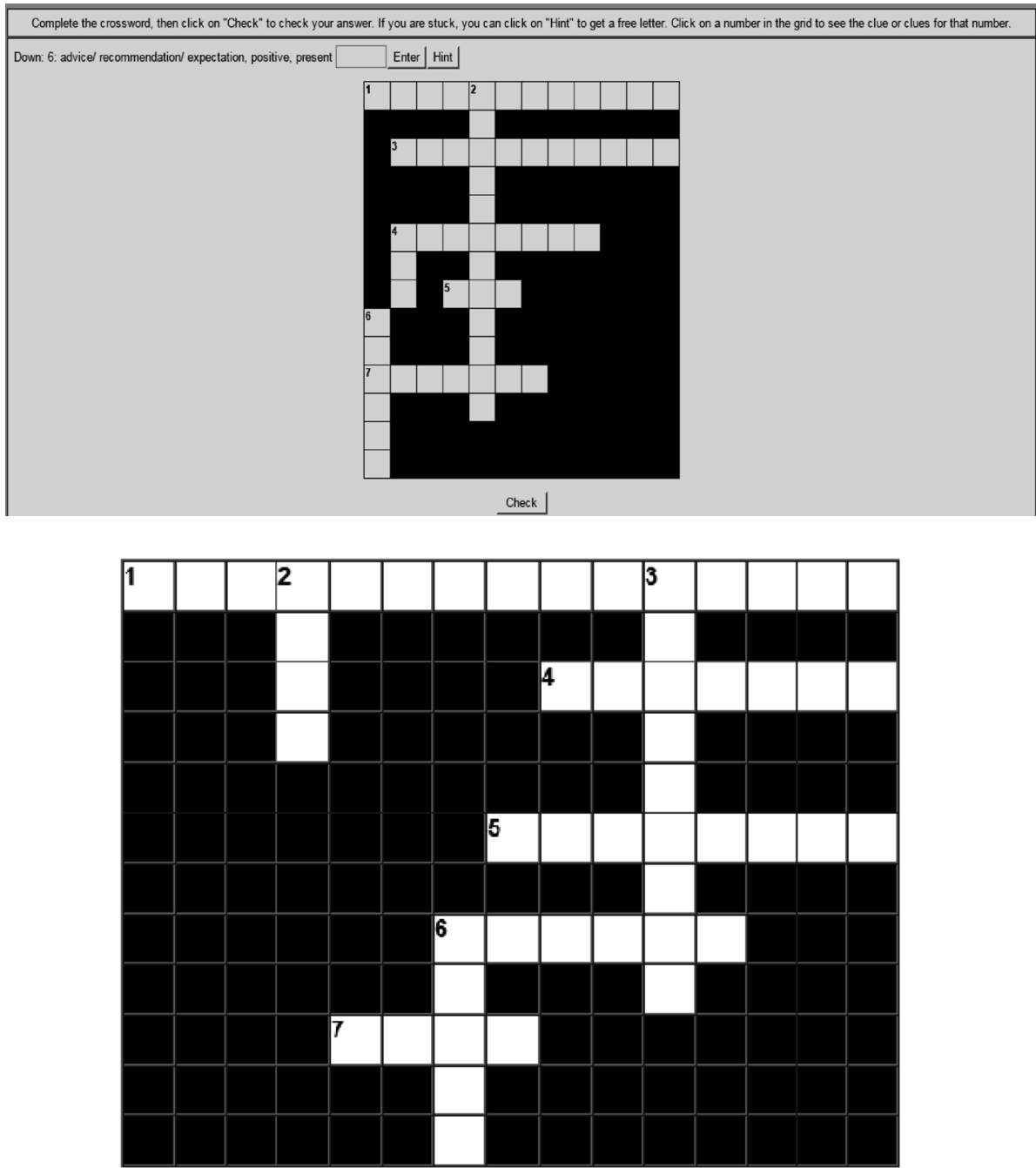

Across:

1 prohibition/ plural/ present

4 prohibition

5 ability/ negative/ past

6 necessity/ plural/ present

7 obligation/ external

\section{Down:}

2 necessity/ plural/ present

3 ability/ singular/ past

6 obligation/ internal/3rd person singular/ present

Figure 4. Comparison of a crossword puzzle created in Hot Potatoes (above) and the crossword puzzle prepared as a hand-out (below). 


\section{Results and discussion}

Based on Thornbury (2002) and Weibel \& Hagen (2011) grammar is best tested by means of discrete-item tests, meaning that individual components of the learner's knowledge are tested. In other words, the same activities used for the presentation and the practice of grammar items can be used for the production and testing. In the case of the research presented here, the meaning of modal verbs was tested based on tasks, such as fill in the gaps, choose the correct answer, match the correct forms, etc. However, since the quasi-experiment conducted for the purpose of this research was based on a combination of grammar-based teaching and the communicative approach, some aspects of an alternative assessment model (Richards \& Renandya, 2002), also referred to as additional assessment by Coombe, O'Sullivan, \& Stoynoff (2012) were introduced. Due to the obvious limitations of this empirical research mentioned in the previous section, specific aspects of alternative assessment practices usually applied in communicative learning, such as continuous and longitudinal assessment or authentic assessment, could not be incorporated. Yet, some characteristics of assessment in communicative learning outlined by Richards and Renandya (2002) and Bailey (1998), such as feedback provided to learners, untimed tests, classroom-based tests and contextualised test tasks could be incorporated in the assessment.

The participants' performance was measured ten times: once in the pretest, twice in week one (presentation), four times in week two (practice), twice in week three (production) and once in the posttest. Since the same experiment was conducted twice, the data analysed in this research were collected in 20 different instances. The performance analysis procedure applied in the assessment followed a clear pattern where the students had to work with a total of 135 sentences. A general consensus was made prior to the assessment that each meaning of a modal verb would be assigned a letter code and a sentence would be deemed incorrect if a completely unacceptable modal verb, modal meaning or tense were used. For instance, in example

[2] Take your coat. They said it might get really cold in the evening. (permission, possibility, advice)

some students circled "advice" instead of "possibility". This answer was marked as incorrect. Similarly, in example see anything. Please, turn the lights on! ability

some students did insert the correct modal verb illustrating the meaning "ability" as asked, but they did not use the correct tense. For instance, many students inserted couldn't instead of can't. This answer was marked as incorrect.

The basic frequency analysis of the total number of mistakes made by the students in each session (Table 1) confirms the hypothesis that the CALL environment proves at least as comprehensive as the conventional classroom. 
Table 1. Total number of mistakes made by the students in all three sessions in both the experimental and the conventional settings

\begin{tabular}{|c|c|c|c|}
\hline Setting & Presentation & Practice & Production \\
\hline Experimental & 61 & 23 & 46 \\
\hline Conventional & 83 & 25 & 121 \\
\hline Total & 144 & 48 & 167 \\
\hline
\end{tabular}

As can be seen, the results indicate that the initial assumption was even exceeded since the data point to the general tendency showing that the number of mistakes made in tasks based on the experimental setting actually decreased from an initial 61 in the presentation session to a final 46 mistakes in the production session. Quite contrary to that, the number of mistakes made in tasks based on the conventional setting increased from an initial 83 to a final 121 mistakes in the production session.

This result was surprising, which is why it was decided to analyse the number of mistakes that the students repeated for one and the same meaning of each modal verb in both the experimental and the conventional settings. In other words, it was necessary to see whether the students had managed to understand the separate meanings of modal verbs covered regardless of the approach applied. A comparison between means in cases where the students repeated one and the same mistake once, twice and three times with the same meaning within each setting respectively was performed. The paired sample statistics (Table 2) showed that the mean value for the number of repeated mistakes with one and the same meaning was significantly higher in the conventional setting than in the experimental setting.

Table 2. Paired Samples Statistics for the number of repeated mistakes made in both the experimental and the conventional settings

\begin{tabular}{|cc|c|c|c|}
\cline { 3 - 5 } \multicolumn{1}{c|}{} & Mean & Std. Deviation & Std. Error Mean \\
\hline Pair 1 & One.E & 3.60 & 2.100 & .297 \\
\hline & One.C & 4.22 & 1.799 & .254 \\
\hline Pair 2 & Two.E & 1.40 & 1.726 & .244 \\
\hline & Two.C & 3.16 & 2.494 & .353 \\
\hline Pair 3 & Three.E & .06 & .424 & .060 \\
\hline & Three.C & .00 & .000 & .000 \\
\hline Pair 4 & Total.E & 5.06 & 3.026 & .428 \\
\hline & Total.C & 7.38 & 3.109 & .440 \\
\hline
\end{tabular}

This result is particularly obvious in the case of students who made the same mistake with one meaning once (the mean value 3.60 in the experimental setting as compared to 4.22 in the conventional setting) and twice (the mean value 3.16 in the conventional setting as compared to 1.40 in the experimental setting). The difference between 
the mean values for the total number of mistakes repeated in the conventional setting is 7.38 as compared to 5.06 in the experimental setting. This difference is rather significant as it clearly points to a better performance in the experimental setting as compared to the conventional one, thus confirming the initial hypothesis that traditional grammar instruction in a CALL environment will prove at least as comprehensive and effective as in a conventional one.

With the aim to confirm the relevance of this result, an additional paired samples test was performed to explore the confidence interval in the mentioned cases (Table 3).

Table 3. Paired Samples Test for the number of repeated mistakes made in both the experimental and the conventional settings

\begin{tabular}{|c|c|c|c|c|}
\hline & & \multicolumn{3}{|c|}{ Paired Differences } \\
\hline & & \multicolumn{2}{|c|}{ 95\% Confidence Interval of the Difference } & \multirow{2}{*}{$\begin{array}{l}\text { Mean } \\
\text { Upper }\end{array}$} \\
\hline & & Upper & Lower & \\
\hline Pair 1 & One.E - One.C & -1.875 & 49 & .067 \\
\hline Pair 2 & Two.E - Two.C & -4.559 & 49 & .000 \\
\hline Pair 3 & Three.E - Three.C & 1.000 & 49 & .322 \\
\hline Pair 4 & Total.E - Total.C & -4.196 & 49 & .000 \\
\hline
\end{tabular}

The test supports the previous finding as the confidence interval is -4.559 in cases of students who made the same mistake with one meaning twice. In addition, the confidence interval is $\mathbf{- 4 . 1 9 6}$ with respect to the total number of mistakes the students repeated in the entire experiment, thus supporting both the previously presented result as well as the overall assumption that traditional grammar instruction in a CALL environment yields positive teaching results.

An obvious and quite unexpected result was that the students displayed weaker performance towards the end of the experiment in many of the activities based on the conventional setting. That is why it was decided to run an additional t-test to see whether the observed difference between the number of mistakes made by the students in the separate steps was significant or not. As stated above, descriptive statistics indicated an increase in the number of mistakes made in the conventional setting and a decrease in the number of mistakes in the experimental setting throughout the entire experiment. The result of the additional t-test analysis (Table 4) indicated that the difference in the mean for the number of mistakes made in the experimental and the conventional setting during week one (presentation) in comparison to the mean for the number of mistakes made in the experimental and the conventional setting in week three (production) was rather significant (3.699 and 6.682 respectively). This result also points to the observed tendency that the students' general performance was better in the experimental setting than in the conventional one. 
Table 4. Paired Samples Statistics for the total number of mistakes made in both the experimental and the conventional settings in all three sessions (presentation, practice, production)

\begin{tabular}{|ll|c|c|c|c|c|}
\cline { 3 - 6 } \multicolumn{1}{c|}{} & \multicolumn{2}{c|}{ Paired Differences } & $\mathrm{t}$ & $\mathrm{df}$ & $\begin{array}{c}\text { Sig. } \\
\text { (2-tailed) }\end{array}$ \\
\cline { 3 - 7 } & \multicolumn{1}{c|}{ Mean } & $\begin{array}{c}\text { Std. Devia- } \\
\text { tion }\end{array}$ & & & \\
\hline Pair 1 & Pres.E.tot - Pres.C.tot & -1.180 & 2.256 & -3.699 & 49 & .001 \\
Pair 2 & Pract.E.tot - Pract.C.tot & -.020 & .869 & -.163 & 49 & .871 \\
Pair 3 & Prod.E.tot - Prod.C.tot & -1.660 & 1.757 & -6.682 & 49 & .000 \\
\hline
\end{tabular}

In brief, the quasi-experiment illustrated that if classroom activities are anchored in traditional grammar teaching methodology, the CALL environment proves as comprehensive as the conventional classroom. According to the results presented here, it seems even more effective, as the performance of the students was generally better in the activities and tasks based on the experimental setting in comparison to the conventional setting. What is more, the performance in the experimental setting gradually improved throughout the research, whereas the performance in the conventional setting declined toward the end of the research. The scope of the quasi-experiment presented here did not provide an opportunity for a more detailed exploration of this particular result so that it remains unaccounted for and should be investigated in a separate study.

\section{Conclusion}

The initial motivation for this research resulted from the obvious necessity to provide a theoretical exploration of valid teaching approaches to be applied in a computer-assisted classroom (among others, Beatty, 2010; Colpaert, 2006; Hall, 2011; Levy \& Stockwell, 2013; etc.). As presented in this article, quite a number of researchers decided to direct their research at justifying pedagogical implications of CALL. A review of the relevant literature points towards the necessity to reintroduce grammar instruction in ELT in general but it could also be discovered that apart from a few attempts at exploring grammar instruction within CALL, research in this field is still scarce. Moreover, this necessity was recognised by the Executive Committee of the European Association for Computer Assisted Language Learning, who decided in 2010 that it was an appropriate time to revise the research policy statement formulated in 1999 as many changes had happened and they should be accounted for, especially in the domain of pedagogy.

The quasi-experiment conducted for the purpose of this research was aimed at testing and evaluating traditional grammar instruction methods and techniques that have been in use for a very long time. It was expected that traditional English language teaching methodology applied in a computer-assisted grammar teaching setting should prove at least as effective as in a conventional setting. By alternating traditional grammar instruction in a conventional classroom setting (based on paper and a whiteboard) and a CALL environment, 50 students at two English language departments were exposed to a set of activities based on traditional grammar instruction. The grammar item taught was 
the meaning of modal verbs while the traditional activity sequencing pattern chosen was the Presentation-Practice-Production model, known as the three Ps. Pursuant to various recommendations and conclusions explored and presented in this article, several traditional teaching techniques (problem-solving, explanations, time lines, drills, written practice, pair work, role plays, etc.) and a combination of grammar-based teaching and communicative learning were applied in the experiment.

The analysis of the results collected in the repeated measures performed throughout the empirical part of this research and presented in the previous section shows that the initial hypothesis was confirmed: the traditional grammar instruction proved as comprehensive and effective in the CALL setting as in the conventional one. More than that, the participants' performance proved to be even better in the CALL setting.

Based on the tendencies observed in the experiment, the following conclusions can be drawn from this research:

Students come to the language classroom as digital natives (Prensky, 2001), i.e. quite acquainted with the use of one of their favourite gadgets - the computer. The skills they already have (Goertler \& Winke, 2008) should be used for a purpose other than entertainment. The research indicates that such use seems to motivate and encourage them to take initiatives and collaborate with their peers in an interactive setting quite different from the conventional classroom setting, yet structured and conducted based on it. An overall positive performance when using the computer for the purpose of education seems justifiable.

The positive results collected in this research show that activities and tasks prepared by means of web-based tools and then used in a CALL classroom have several advantages over conventional paper-based material, such as:

(a) Appealing and stimulating presentation of material (cartoons, video, images, hyperlinks to other content, etc.) so that the overall organisation of a computerassisted class proves to be more dynamic, flexible and productive (Cennamo, 1993; Vanderplank, 2010);

(b) Independent decision-making (Murphy, 2008), accompanied with help options and immediate feedback (Hyland, 2000; Skehan, 2003) provided in the tools used in class, together contribute to an increase of self-confidence as students' lack of knowledge is less exposed to the group;

(c) Collaborative tasks usually difficult to realise in a conventional setting, such as think-pair-share and project-based learning are quite easy to incorporate in a CALL setting because the tasks are performed online, immediately shared by the entire group and everything that has been covered in class is available and accessible out of the class as well (Kirschner et al., 2004; Kukulska Hulme \& Shield, 2008).

As has been presented here, teaching techniques applied for the purpose of furthering interaction among students, thus enhancing comprehension based on the communicative learning approach, if supported by structured grammar-based teaching and based on a clearly outlined model, have been verified and proven effective for decades. This research has shown that applying such grammar instruction in a CALL setting proves to be as effective and comprehensive if it follows already verified methodological conventions. 
Incorporating them into the CALL environment only makes them more interesting and appealing thus yielding positive performance.

A list of equal length and with at least the same number of points can be made stating the negative aspects of teaching in a CALL environment. That is exactly why more thorough and more detailed research will have to be directed at the following objectives:

(d) Incorporate, test, evaluate and assess existing and verified ELT methodology in computer-assisted teaching for different learning objectives, language skills and purposes;

(e) Design and create new approaches and methods based on the traditional ones to make them fit the specific practical implications of teaching with computers;

(f) Perform evaluations and assessments of learning and/or teaching systems and introduce necessary changes to ensure the proper implementation of CALL, such as curriculum and syllabus adjustments, teacher training, assessment procedures, equipment needs, etc.

It may be expected that such research will not only provide a structured and systematic approach to CALL, but also a reliable system that will enhance and justify a broader application of computers in English language teaching.

\section{References}

Akakura, M. (2012). Evaluating the Effectiveness of Explicit Instruction on Implicit and Explicit L2 Knowledge. Language Teaching Research, Vol. 16, No. 1, 9-37.

Al Jarf, R. (2004). The Effects of On-Line Grammar Instruction on Low Proficiency EFL College Students' Achievement. The Asian EFL Journal Quarterly, Vol. 7, No. 4, 166-190.

Azar, B. \& Matthies, B. F. (2003). Fundamentals of English Grammar - Teacher's Guide. Third Edition. New York: Pearson Education.

Azar, B. (2007). Grammar-Based Teaching: A Practitioner's Perspective. TESL-EJ, Vol. 11, No. 22, 1-12.

Bailey, K. M. (1998). Learning about Language Assessment: Dilemmas, Decisions, and Directions. Pacific Grove: Heinle \& Heinle.

Baturay, M. H., Dalaglu, A. \& Yildirim, S. (2010). Language Practice with Multimedia Supported WebBased Grammar Revision Material. ReCALL, Vol. 22, No. 3, 313-331.

Beatty, K. (2010). Teaching and Researching: Computer-Assisted Language Learning. Second International Edition. London: Pearson Education.

Brown, H. D. (2000). Principles of Language Learning and Teaching. Fourth edition. New York: Longman.

Broughton, G., Brumfit, C., Flavell, R., Hill, P. \& Pincas, A. (1978). Teaching English as a Foreign Language. London: Routledge \& Kegan Paul.

Cameron, K. (2001). C.A.L.L. - the Challenge of Change: Research and Practice. Exeter: University of Exeter.

Carter, R. \& Nunan, D. (2001). Teaching English to Speakers of other Languages. Cambridge, UK: Cambridge University Press. 
Cennamo, K. S. (1993). Learning from Video: Factors Influencing Learners' Preconceptions and Invested Mental Effort. Educational Technology Research and Development, Vol. 41, No. 3, 33-45.

Chapelle, C. A. (1997). CALL in the Year 2000: Still in Search of Research Paradigms. Language Learning \& Technology, Vol. 1, No. 1, 19-43.

Cheng, H. F. \& Dörnyei, Z. (2007). The Use of Motivational Strategies in Language Instruction: the Case of EFL Teaching in Taiwan. Innovation in Language Learning and Teaching, Vol. 1, No. 1, 153-174.

Colpaert, J. (2006). Pedagogy-Driven Design for Online Language Teaching and Learning. CALICO Journal, Vol. 23, No. 3, 477-497.

Coombe, C., O'Sullivan, B. \& Stoynoff, S. (2012). The Cambridge Guide to Second Language Assessment. Cambridge: Cambridge University Press.

Coniam, C. (2006). Evaluating Computer-Based and Paper-Based Versions of an English-Language Listening Test. ReCALL, Vol. 18, No. 2, 193-211.

Cook, V. (2008). Second Language Learning and Teaching. Fourth edition. London: Hodder Education.

Ellis, N. C. \& Bogart, P. (2007). Speech and Language Technology in Education: The Perspective from SLA Research and Practice. In SlaTE-2007, 1-8. Retrieved July 10, 2015 from the World Wide Web http://www.isca-speech.org/archive_open/slate_2007/sle7_001.html

Ellis, R. (2002). The Place of Grammar Instruction in the Second/Foreign Language Curriculum. In E. Hinkel, \& S. Fotos (Eds.), New Perspectives on Grammar Teaching in Second Language Classrooms (pp. 17-34). Mahwah: Lawrence Erlbaum Associates.

Ellis, R. (2006). Current Issues in the Teaching of Grammar: an SLA Perspective. TESOL Quarterly, Vol. 40 , No. 1, 83-107.

Fernando, R. A. (2007). Top of the Pods - in Search of a Podcasting "Pedagogy" for Language Learning. Computer Assisted Language Learning, Vol. 20, No. 5, 471-492.

Goertler, S. \& Winke, P. M. (Eds.) (2008). Opening Doors through Distance Language Education: Principles, Perspectives and Practices. San Marcos: Texas State University, Computer Assisted Language Instruction Consortium.

Hall, G. (2011). Exploring English Language Teaching: Language in Action. Oxon: Routledge.

Harmer, J. (1996). Is PPP Dead? Modern English Teacher, Vol. 5, No. 2, 7-14.

Harmer, J. (2001). The Practice of English Language Teaching. Third Edition. London: Longman.

Hyland, F. (2000). ESL Writers and Feedback: Giving More Autonomy to Students. Language Teaching Research, Vol. 4, No. 1, 33-54.

Jarvis, H. \& Szymczyk, M. (2010). Student Views on Learning Grammar with Web-and BookBased Materials. ELT Journal, Vol. 64, No. 1, 32-44.

Kern, R. (2006). Perspectives of Technology in Learning and Teaching Languages. TESOL Quarterly, Vol. 40, No. 1, 183-210.

Kirschner, S., Strijbos, J., Kreijns, K. \& Beers, P. (2004). Designing Electronic Collaborative Learning Environments. Educational Technology Research and Development, Vol. 52, No. 3, 47-66.

Koehler, M. J. \& Mishra, P. (2008). Introducing TPCK. In Handbook of Technological Pedagogical Content Knowledge (TPCK) for educators (pp. 3-29). New York: Routledge.

Kukulska Hulme, A. \& Shield, L. (2008). An Overview of Mobile-Assisted Language Learning: From Content Delivery to Supported Collaboration and Interaction. ReCALL, Vol. 20, No. 3, 271-289. 
Levi, M. (1997). CALL: Context and Conceptualisation. Oxford: Oxford University Press.

Levy, M. \& Stockwell, G. (2013). CALL Dimensions: Options and Issues in Computer-Assisted Language Learning. New York: Routledge.

Lewis, M. (1996). Implications of a Lexical View of Language. In D. Willis \& J. Willis (Eds.), Challenge and Change in Language Teaching (pp. 10-16). Oxford: Heinemann

Lightbrown, P. M. \& Spada, N. (2006). How Languages are Learned. Oxford: Oxford University Press.

Mulroy, D. (2003). The War Against Grammar. Portsmouth: Boynton and Cook Publishers, Inc.

Murphy, L. (2008). Supporting Learner Autonomy: Developing Practice through the Production of Courses for Distance Learners of French, German and Spanish. Language Teaching Research, Vol. 12 , No. 1, 83-102.

Nassaji, H. \& Fotos, S. (2004). Current Developments in Research on the Teaching of Grammar. Annual Review of Applied Linguistics, Vol. 24, 126-145.

Noels, K. A. (2001). Learning Spanish as a Second Language: Learners' Orientations and Perceptions of their Teachers' Communication Style. Language Learning, Vol. 51, No. 1, 107-144.

Nunan, D. (2005). Task-Based Language Teaching. Cambridge: Cambridge University Press.

Parrott, M. (2000). Grammar for English Language Teachers. Cambridge, UK: Cambridge University Press.

Pennington, M. C. (2002). Grammar and Communication: New Directions in Theory and Practice. In E. Hinkel \& S. Fotos (Eds.), New Perspectives on Grammar Teaching in Second Language Classrooms (pp. 77-98), Mahwah: Lawrence Erlbaum Associates.

Prensky, M. (2001). Digital Natives, Digital Immigrants. On the Horizon, Vol. 9, No. 5, 1-6.

Richards, J. C. \& Renandya, W. A. (2002). Methodology in Language Teaching. Cambridge: Cambridge University Press.

Richards, J. C. \& Rodgers, T. S. (2014). Approaches and Methods in Language Teaching. Cambridge: Cambridge University Press.

Sánchez, A. (2001). Sequencing of Activities and Motivation. In V.Codina Espurz \& E. Alcón Soler (Eds.), Language Learning in the Foreign Language Classroom (pp. 116-132). Castellón: Universidad Jaume $\mathrm{I}$.

Scrivener, J. (1994). PPP and after. The Teacher Trainer, Vol. 8, No. 1, 15-16.

Skehan, P. (2003). Focus on Form, Tasks, and Technology. Computer Assisted Language Learning, Vol. 16 , No. 5, 391-411.

Stockwell, G. (2007). A Review of Technology Choice for Teaching Language Skills and Areas in the CALL Literature. ReCALL, Vol. 19, No. 2, 105-120.

Swan, M. (2005). Legislation by Hypothesis: The Case of Task-Based Instruction. Applied Linguistics, Vol. 26, No. 3, 376-401.

Teruya, K. (2009). Grammar as a Gateway into Discourse: A Systemic Functional Approach to Subject, Theme and Logic. Linguistics and Education, Vol. 20, No. 1, 67-79.

Thomson, A. J. \& Martinet, A. V. (1990). A Practical English Grammar. Oxford: Oxford University Press.

Thompson, A. \& Mishra, P. (2008). Breaking News: TPCK Becomes TPACK! Journal of Computing in Teacher Education, Vol. 24, No. 2, 38-64.

Thornbury, S. (2002). How to Teach Grammar. Harlow: Pearson Education Ltd. 
Ur, P. (1991). A Course in Language Teaching - Practice and Theory. Cambridge: Cambridge University Press.

Vance, L. K. (2012). Do Students Want Web 2.0? An Investigation into Student Instructional Preferences. Journal of Educational Computing Research, Vol. 47, No. 4, 481-493.

Vanderplank, R. (2010). Déjà vu? A Decade of Research on Language Laboratories, Television and Video in Language Learning. Language Teaching, Vol. 43, No. 1, 1-37.

Weibel, K. R. \& Hagen, S. A. (2011). Test Bank for Fundamentals of English Grammar. Fourth edition (The Azar-Hagen grammar series). Harlow: Pearson Longman.

Wold, K. A. (2011). Blending Theories for Instructional Design: Creating and Implementing the Structure, Environment, Experience and People (SEEP) Model. Computer Assisted Language Learning, Vol. 24, No. 4, 371-382.

Woodward, T. (1993). Changing the Basis of Pre-Service TEFL Training in the U.K. IATEFL TT SIG Newsletter, Vol. 13, No. 1, 3-5. 


\title{
НАСТАВА ЕНГЛЕСКОГ ЈЕЗИКА УЗ ПРИМЕНУ РАЧУНАРА: ТЕСТИРАЬЕ И ВРЕДНОВАЊЕ ТРАДИЦИОНАЛНОГ ПРИСТУПА НАСТАВИ ГРАМАТИКЕ
}

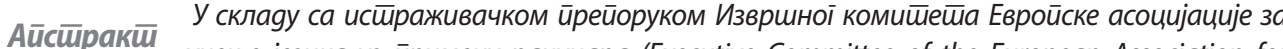
учене језика уз иримену рачунара (Ехесutive Committee of the European Association for

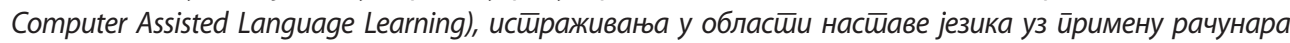

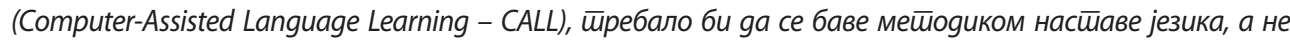

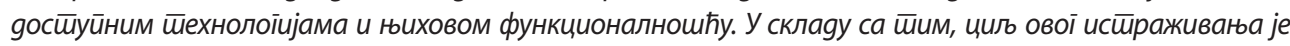

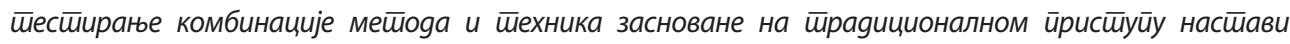

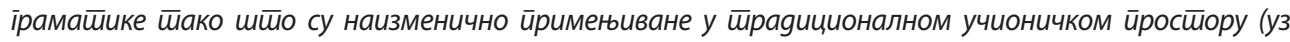

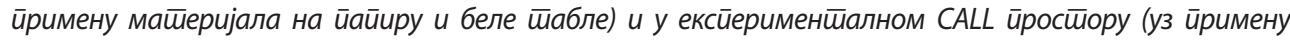

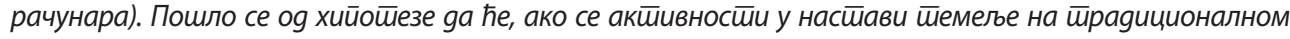

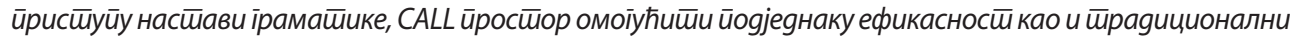

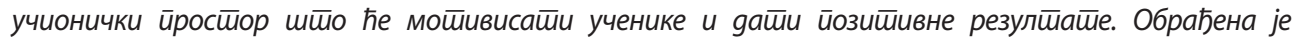

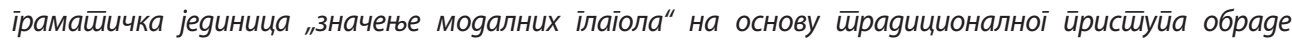

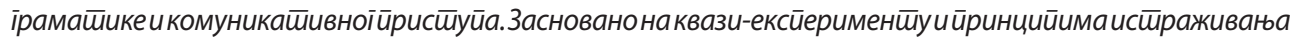

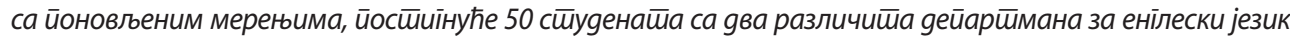

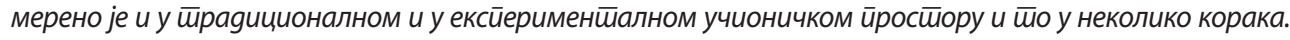

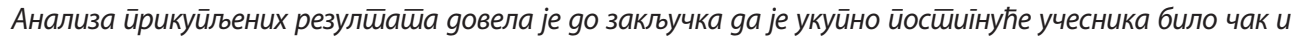

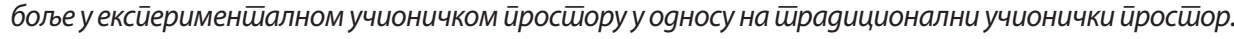

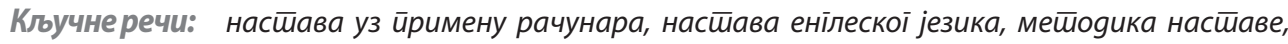

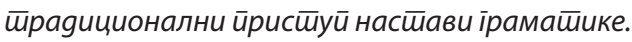

\section{ОБУЧЕНИЕ АНГЛИЙСКОМУ ЯЗЫКУ С ПОМОЩЬЮ КОМПЬЮТЕРА: ТЕСТИРОВАНИЕ И ОЦЕНКА ТРАДИЦИОННОГО ПОДХОДА К ПРЕПОДАВАНИЮ ГРАММАТИКИ}

\begin{abstract}
Резюме Согласно рекомендации Исполнительного комитета Европейской ассоциации по изучению языка с использованием компьютеров (Exесutive Committee of the European Association for Computer Assisted Language Learning), исследования в области преподавания иностранных языков с использованием компьютеров (Computer Assisted Language Learning - CALL) должны заниматься методикой преподавания языка, а не доступной технологией и ее функциональностью. Соответственно, иель данного исследования заключается в проверке комбинации методов и приемов, основанных на традиционном подходе к обучению грамматике, так что попеременно применялись в традиционном (с использованием материалов на бумаге и на доске) и экспериментальном классе (с использованием компьютеров). Основная гипотеза заключалась в следующем: если обучение в классе строится на традиционном подходе к обучению грамматике, тогда применение компьютера обеспечит такую же эффрективность как и пространство традиционного классаи, к томуже, дополнительно мотивирует учеников и дает положительные результаты. Обработана грамматическая тема "Значение модальных глаголов", с применением традиционного подхода к обучению грамматике и коммуникативного подхода. На основе квази-эксперимента и исследования с повторной оценкой достижения 50 студентов двух различных департманов английского языка проверялись и в традиционном и в экспериментальном пространстве класса. Анализ полученных результатов привел квыводу, что общий успех участников был лучше в экспериментальном, чем в традиционном классе.
\end{abstract}

Ключевые слова: обучение с использованием компьютеров, преподавание английского языка, методика обучения, традиционный подход к преподаванию грамматики. 